\title{
CZECH CURRICULAR REFORM IN THE REAR-VIEW MIRROR: THE CASE OF FOREIGN LANGUAGE LEARNING
}

\author{
Pavel Brebera \\ Language Centre, University of Pardubice (Czech Republic)
}

\begin{abstract}
The aim of the paper is to present some insights into the long-term effects of the Czech curricular reform, which was carried out at primary and lower-secondary level of educational system in the second half of the previous decade. The author combines two relevant perspectives. The first viewpoint is represented by referring to the outcomes of the author's own longitudinal empirical research, which was carried out within the years 2004-2007. The aforementioned study was focused on analysing the particular dimension of English language teachers' professional competence in relation to the proclaimed goals of the upcoming curricular reform. The second perspective intends to provide a valuable complementary picture as it is based on the analysis of "language learning stories", expressed by the current university students, i.e. the addressees of the previous curricular reform. This small-scale empirical investigation was carried out via a content analysis of the students' reflections on their prior learning experience. The arising categories of qualitative data are interpreted with regard to the main principles of the curricular reform, and discussed in terms of some potential ways of dealing with the issues of the university students' previous language learning experience.
\end{abstract}

Keywords: English language learning, university students, teacher professional competence, curricular reform.

\section{Introduction}

Over the past fifteen years, the Czech educational system has undergone numerous changes in terms of the proclaimed goals of education, as well as of its content. One of the key topics of the Czech pedagogical discourse in the previous years was the so-called curricular reform. The idea of the two-level curriculum, consisting of the national curriculum (i.e. Framework Educational Programmes for the particular levels of educational system) as the basis for creating the context-specific school curricula (i.e. the respective School educational programmes), was expected to bring the desirable changes directed towards long-term positive educational effects.

The obvious demands of carrying out the curricular reform successfully have always included both the aspects of its temporal characteristics and the issues of an active involvement of teachers as key agents of the reform. Besides, the need for perceiving this reform as a long-term process is clearly formulated e.g. by Vrabcová and Pázlarová (2016, pp. 294-295), who distinguish between the so-called period of systemic reconstruction (1999-2004), general implementation (2005-2011) and reform modification (2012 and later). Furthermore, their empirical analysis deliberately focuses on the area of teachers' attitudes, similarly to the studies of other authors in the Czech educational context during the "reform modification period", which have been carried out with the intention to analyse its effectiveness (e.g. Janík et al. 2018 at secondary grammar schools, or Pešková et al. 2018 at primary schools).

The main aim of this text is to reflect back on the "general implementation" period of the curricular reform through "the voices" of current university students of non-pedagogical study fields. However, a useful starting point of further analyses might be found in drawing some parallels between the outcomes of our own long-term empirical research conducted during the "general implementation" period (namely 2004-2007) and some current findings related to the subsequent "reform modification stage".

\section{Perspectives on the curricular reform "at that time" and "at the moment"}

It has been previously mentioned that the curricular reform primarily focused on new roles of teachers in real-life school environments. General interest in the empirical evidence in the area of new 
teacher competences was reflected in numerous research studies, such as the one conducted by Straková et al. (2014), intended to find out whether the teachers "identify with the aspects of curricular reform that are new and have no tradition in the Czech school" (Straková et al. 2014, p. 65). A similar aim was previously formulated also for our longitudinal empirical research from the period 2004-2007 (Brebera 2008,2010 ), which represented the so-called "preparatory period" of the curricular reform at primary and lower-secondary schools, i.e. before the official launch of the two-level curriculum system for these schools. We investigated into the competences of novice teachers in the area of curricular design, and we identified a very important determinant of the teacher professional development within the particular school culture. Our results showed that the outside pressure on schools, which were suddenly expected to perform as potential professional learning communities (the term according to Persson 2006, p. 35; similarly Shulman \& Shulman 2004, in their influential model of multi-level teacher learning), sometimes even produced the type of results quite contrary to the proclaimed goals of the reform. Our empirical evidence showed that the general perceptions of professional learning opportunities in schools could be characterised in terms of "learning ignored" (in 2004-5), "learning rejected" (in 2005-6) and "learning imposed" (in 2006-7) (Brebera 2008, pp. 12-13). Similarly, some current reflections on the curricular reform in various contexts show e.g. that it "has been accepted by the Czech grammar school teachers to a limited extent" (Janík et al. 2018, p. 66), which concerns both the so-called "subject/content-oriented teachers" and the "student-oriented" ones (ibid). Moreover, there certainly exist noticeable individual differences in the teachers' attitudes to the reform, characterised e.g. by Pešková et al. (2018) as "positive - supporting, neutral - balancing and negative - disenchanted" (Pešková et al. 2018, p. 69).

An excellent complementary viewpoint to the previously presented general perspective on the curricular reform could be found in the empirical research carried out by Černá et al. (2016) in the field of foreign language learning. This study appears to be really valuable, mainly owing to the fact that the authors investigated into individual foreign language learning stories of the research subjects who were directly affected by the implementation of the curricular reform. This study involved a relatively large group of the students of English language teaching programmes, it is based on a very complex and precisely elaborated research methodology and presents very useful and deep insights into the role of formal learning contexts but also the non-formal and informal ones in the process of building the attitudes towards English language learning.

Here below, we try to offer the results of our own small-scale empirical investigation, carried out with a similar intention, i.e. researching the perceived impact of various types of language learning experience, acquired during the era of curricular reform, on the attitudes towards foreign language learning. Nevertheless, in our research context we deal with a different researched population, which consists of purely non-philological students. Besides, our viewpoint primarily intends to offer a synthesis of the key categories that appeared in the perceptions of the novice teachers during the era of "triggering the curricular reform" (i.e. 2004-2007, in Brebera 2010), with the reflections on the corresponding concepts, as expressed by current non-philological students. To sum it up, the novice teachers' perspective from the period 2004-2007 is represented by the following broad categories: "teachers as agents of change, aims and competencies, educational content, textbooks, and cross-curricular links" (ibid, pp.135-139). Accordingly, the key concepts that have been deliberately chosen as the basic structure for categorising the current respondents' reflections are: my language teachers, my language achievements, my favourite and disliked areas of language learning, my textbooks, and my use of English for real-life purposes.

\section{Empirical evidence}

\subsection{Research methodology, context and participants}

It has already been mentioned that the aim of our empirical research was to identify the specifics of previous learning experience in the group of non-philological university students. Therefore, the researched population consisted of the students of Bachelor degree study programmes in the field of transport engineering, who enrolled into the particular one-semester intermediate courses of English for Transport (i.e. B1 and B1+ according to the Common European Framework of Reference for Languages) in the period 2014-17. Altogether, 71 students were involved in this empirical investigation.

The research included the qualitative part based on the content analysis of the student-generated material within the specific blended learning task, and the quantitative part based on the feedback data related to the previously mentioned task, collected by means of a semi-structured questionnaire. The format of the student-generated material was defined in terms of the spoken presentation, entitled "My language learning story". In their narratives, the students were expected to reflect on their language learning achievements during their university studies via commenting on their collection of the so-called digital badges (for more about this particular blended task, see Brebera, Bezdíčková 2019, pp. 95-96), and 
they were also invited to present their prior learning experience in other contexts. The research results, which are presented below, are based on the aforementioned qualitative part (for the results of the quantitative part, see Brebera, Bezdíčková 2019, pp. 96-99).

\subsection{Research results}

3.2.1. Teachers as agents of change / My language teachers. The empirical research from the period 2004-2007 revealed a huge variety of perceived attitudes towards change in schools. In some schools, the curricular reform was obviously perceived as a great opportunity for innovations: “... I would say that the teachers at our school are very progressive and open to any changes that would generally improve teaching ..." (Brebera 2010, p. 146). On the other hand, numerous sceptical observations related to the acceptance of the curricular reform appeared as well: "I had a feeling from the teachers here that they were staring at me and grumbling: What the hell is she trying to do? Does it mean that also we will have to do something extra?" (ibid. 149).

The obvious variability in terms of the continuum ranging from "progressive teachers" towards the "resistant" ones was reflected also in the current students' memories of their primary and secondary schools studies. A negative aspect that was mentioned quite frequently was the teachers' turnover, e.g.: "I don't remember much because we had three teachers and it was not good". Besides, some comments manifested the pupils' disappointment related to their teachers' professional competencies, e.g.: "Our teacher knew less than we did. Lessons were boring with her and such a shame, it resulted that I lost an interest in English;" or "It was in the $7^{\text {th }}$ class. We learned new words and there was the word model train. I like the trains and the model trains but the teacher said it isn't an important word for us because it won't be in the exam". However, also the excitement connected with the experience of having highly competent teachers still stays in the memories of the current university students, e.g.: "At the elementary school, I liked my English teacher. He was very nice. I liked English;" or "We had a teacher who was always in England. So, her English is really good and the experience from the lessons with her is unforgettable." Based on that, a conclusion might be drawn that the new generation of school pupils seems to be aware of a huge impact of their former teachers on their attitudes towards language learning. This fact might be one of the incentives for the forthcoming reform efforts.

3.2.2. Aims and competencies / My language achievements. One of the main ideas of the curricular reform was to focus on the development of the learners' competencies. The positive efforts of some of the teachers in this area were rewarded by some clearly observable pupils' achievements and at the same time, they produced a higher level of the teachers' job satisfaction: "I know that it may take a long time, maybe even several years. But I want to do it this way. I am really happy that something will change. I really like it because I will be happy that I could do the project work at the elementary school. Before I started studying the teacher training programme I didn't even know what project work is. And then I tried it out with the children, first only short-time and a short project. And they were so happy and liked it so much when they were actively searching for new information. And what they also liked about it was that their projects were displayed and everybody could look at them" (Brebera 2010, p. 146). On the other hand, the newly formulated focus on the category of competencies was sometimes openly questioned: "The key competencies are certainly important for the child and his/her life. On the other hand, they do not guarantee that the child will be able to pass the entrance exam for the secondary school or get a good job if he/she doesn't have theoretical knowledge. I talked about it with my colleagues at school and they think the same" (ibid. p. 163).

As regards the current university students' perceived language achievements, they were very often expressed in terms of school grades, e.g.: "I always wanted English just because of school, because I needed good marks;" especially in connection to the so called "maturita exam", i.e. final secondary school exam: "The teacher was strict, it was really hard, I got bad marks and I hated English at the grammar school. But after this hell with the teacher, the "maturita" exam was easy." Besides, the perceived language achievements demonstrable outside the formal school context also appeared in the reflections, and they concerned mainly the experience of being successful in real-life communicative situations, e.g.: "I liked meeting new people and new language, I am very interested in languages. First of all, learning is about culture which is connected with the language. Then I tried to speak about everything with the native speaker when I was on holiday or some visitor came to our class; " or "When I was younger I travelled a lot with my family and I was the only one who knew a few English sentences because my family know just Russian and German language". These comments point out that the students still attach equal importance both to "learning for life" and "learning for school". 
3.2.3. Educational content / My favourite and disliked areas of language learning. According to many comments from the period 2004-2007, the task of writing the school curriculum was often perceived as a formal one: "Everybody says that in fact, nothing will really change, and that the teachers will just re-write the things they have already been using for years, and they will just use a different label for them" (Brebera 2010, p. 148). Nevertheless, other teachers undoubtedly demonstrated a very responsible approach in the area of designing the educational content within the study subject English language: "I think it should be something like a broader framework so I decided to design it in this way: Reading skills - shopping, free time, holiday postcard; writing skills - holiday postcard; listening skills - free time, etc. And I also added the recommended aids - cassette player, postcards, textbook, worksheets, picture cards, etc." (ibid, p. 163).

The current students' voices clearly reveal how the choice of the specific content might influence the attitudes towards language learning either negatively ("This English was very hard because we learned by heart long topics, it was terrible and I hated it") or positively ("Especially at the grammar school, I liked small groups of people, and we communicated together and needed to maybe run some meetings or do some interviews together"). From a more general perspective, the newly arising requirement of studying two foreign languages at the primary level was occasionally questioned ("In the eighth class I started learning German and it makes me problems sometimes because I am mixing these two languages. And sometimes it works like I mean something in Czech, then translate in German and finally I can say it in English."). Based on the previous comments, the choices of the educational content, made at the level of formulating general language policies as well as in real schools, seem to be absolutely vital from the perspective of creating a meaningful and well-functioning educational system.

3.2.4. Textbooks / My textbooks. Perhaps the most frequently discussed topic in the unstructured teachers' debates in our research from 2004-2007 was the issue of textbooks. The curricular reform was intended to encourage the creative way of using various teaching materials and this idea was also reflected in many comments on the new school curriculum development: "My colleagues also like working with this textbook. This textbook contains many funny stories about the family. The pupils like the dramatization of these stories. And it is also full of songs" (Brebera 2010, p. 152). On the other hand, the need for avoiding an overdependence of the new school curricula on the particular textbooks was expressed as well: "In our teams, we discussed the importance of textbooks and concluded that the aims and textbooks are important but the curriculum should not be based on them. We stated the outcomes for each grade but not according to textbooks. The reason was that if we decided to change the textbook in the future we would have to re-write the whole curriculum. " (ibid. 163).

Unlike the aforementioned teachers' huge interest in the issues of textbooks, the current students' reflections on the period of their primary and secondary school studies included only occasional remarks on the textbooks and classroom materials. They appeared only in the case of describing the specific learning context ("in the kindergarten... we couldn't read, we were learning from picture books") or in case of strongly positive emotions ( "...this is my first textbook. The magnificent Chit Chat which was full of pictures and illustrations. It's really the first thing that came to my mind if someone asks me how I started learning English."). Implicitly, the comments on the classroom materials appear in the descriptions of preferred activity types, such as e.g. "We did a lot of reading with the magazine $R$ and $R$. and in this magazine there are lots of crosswords. I like crosswords." This fact implies that the categories of educational content and the teaching materials are to a certain extent overlapping both in the teachers' as well as the students' perceptions.

3.2.5. Cross-curricular links / My use of English for real-life purposes. The new system of curricular documents also supported the idea of creating meaningful links across the whole school curriculum. This aspect of designing the new school curricula represented a very complex task for the teachers but sometimes it was questioned even from the part of the students, e.g.: "I was really surprised when we were talking about English speaking countries and the $7^{\text {th }}$ graders told me that the biggest English speaking country is China and that they really did mean it. After a long discussion they told me that English classes are not Geography ones and that on English lessons they didn't need to know these things. I was really shocked" (Brebera 2010, p. 155). Nevertheless, the potential of interconnecting the educational content of English language with other subjects appeared in many practical recommendations, such as e.g.: "I might hate anything that is connected to physics but I don't agree that it is useless to connect English to physics. When you come to England and you want to buy something, the knowledge of our measures would be useless for you there... So why don't we use it for connecting both subjects miles, pounds, etc.... After all, when the kids come to England one day this might be more useful for them than to know where Shakespeare used to live" (ibid, p.161). 
In their reflections, the current university students, who are predominantly technically-oriented, very often commented on practical language learning opportunities beyond the scope of formal school curricula, i.e. mainly films, series and sports on TV, PC games and holiday trips. The school-related opportunities for establishing the links between the acquired language skills and other study areas were expressed mainly in terms of the appreciation of school exchange programmes ("This photo is from the secondary school when we were with friends and a teacher on Erasmus plus.... We studied about ecology and renewable energies. The teacher was from India so the communication was pretty hard but we made it"), or following the particular professional interests ("At the secondary school I explored that English could be important for $3 D$ modelling and graphics. There was and still is the professional vocabulary which I can get to know.") Apparently, in the area of reflecting on the power of foreign language learning across the curriculum, our specific group of technically-oriented respondents demonstrated the highest level of personal fulfilment in accordance with the proclaimed principles of the curricular reform.

\section{Conclusion and discussion}

There are two main reasons for using the metaphor of a rear-view mirror in connection to the curricular reform in the title of this text. Firstly, we intended to emphasise the general importance of stimulating the reflective thinking and developing the metacognitive skills related to language learning. Secondly, the metaphor was supposed to characterise our researched group, i.e. the future professionals in the area of transport engineering, since the concept of rear-view mirror represents a relatively relevant technical expression used within this particular professional group. In short, we may assume that the aspects of both "looking back" and "thinking forward" with regard to one's professional needs represent one of the essential components of English language education at the tertiary level.

Besides, it was proved that the concepts which produced such strong feelings among the novice teachers during the initial stage of the curricular reform (i.e. 2004-2007) resonate to a certain extent also in unstructured reflective narratives of the people who experienced this era from the student's perspective. Therefore, there appears to exist a clear conceptual inter-relation between those who provide the education and those in the role of its recipients, in this case the "addressees" of the curricular reform. In conclusion, our findings imply that the long-term effects of the curricular reform are always worth investigating since they may serve as a very useful basis for shaping the particular educational policies at the present time as well as in the future.

\section{References}

Brebera, P. (2010). Curriculum design: a means of an English language teacher professional development. Doctoral dissertation. Brno: Masarykova univerzita. Retrieved February 13th, 2020, from http://is.muni.cz/th/117766/ff_d/?lang=en;id=196552 .

Brebera, P. (2008). The challenge of becoming a learning teacher: some notes on change agency in the Czech educational context. The Learning Teacher Journal, 2008, Volume 2, Number 1, pp. 3-18.

Brebera, P. \& Bezdíčková, Z. (2019). Supporting Blended Learning in ESP Courses: Switching Between "Online", "Offline" and "Onstage". In Ørngreen, R.; Buhl, M.; Meyer, B. (eds.) Proceedings of the 18th European Conference on e-Learning. ECEL 2019 (pp. 93-101). Reading: Academic Conferences and Publishing International Limited.

Černá, M. et al. (2016). Routes and Destinations. Learning histories of Czech speakers of English and their achievement in selected communicative language competencies. Pardubice: University of Pardubice, 2016.

Janík, T. et al. (2018) Czech Teachers' Attitudes Towards Curriculum Reform Implementation. Human Affairs 28, pp. 54-70.

Persson, M. (2006). A Vision of European Teaching and Learning. Perspectives on the new role of the teacher. Karlstad: The Learning Teacher Network.

Pešková, K. et al. (2018). The Changes of Teachers' Attitudes Towards Curricular Reform and Its Implementation. Orbis Scholae, 2018, 12(1), pp. 69-93.

Shulman, L.S. \& Shulman, J.H. (2004). How and what teachers learn: a shifting perspective. Journal of Curriculum Studies, 2004, Vol. 36, No. 2, pp. 257-271.

Straková, J. et al. (2014). The Professional Convictions of Teachers and Basic (Elementary) Schools and of Students at Faculties Training Future Teachers. Pedagogika 64(1), pp. 34-65.

Vrabcová, D. \& Pazlarová, A. (2016). Czech teachers' attitudes to contemporary school curricular reform: current view. Procedia - Social and Behavioral Sciences 217, pp. 293-302. 